\title{
Biodiversity of White Grub, (Coleoptera: Scaraeidae) in Semi-Arid Agro-Ecosystem of Rajasthan
}

\author{
B L JAKHAR ${ }^{1}$, AS BALODA ${ }^{1}$, MD CHOUDHARY ${ }^{2}, K^{K}$ SAINI $^{1}$, M L JAKHAR AND T YADAV ${ }^{1}$
}

\begin{abstract}
White grubs are the major insect pests of cultivated plants in semi arid agro-ecosystem of Rajasthan. It is important to understand diversity, abundance and distribution of scarabaeid beetles for planning effective pest management programme. The experimental data were collected from 9nine locations in 3three different ecosystems in Kharif season of year 2019. Species identification revealed that there was total 9nine species were recorded from 18885 specimens collected. The identified species were belongs under 2two subfamilies of Scarabaeidae family. Maximum specimens were collected in the month of July from selected sites. When species diversity was compared among different locations, it was found that Shannon Wiener diversity index varied from 1.235 to 1.095 which1.095, which indicates that species were less diverse but frequently present. . The present study can be used to formulate the integrated pest management strategies based on most abundance and diverse scarabaeids in semi-arid agro-ecosystem of Rajasthan.
\end{abstract}

\section{KEYWORDS}

Biodiversity, white grub, species, distribution
ARTICLE INFO

\begin{tabular}{lll} 
Received on & $:$ & $20 / 03 / 21$ \\
Accepted on & $:$ & $21 / 05 / 21$ \\
Published online & $:$ & $30 / 06 / 21$ \\
\hline
\end{tabular}

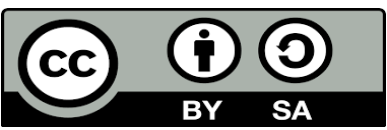

\section{INTRODUCTION}

$\mathrm{S}$ carabaeidae is the largest family of the order Coleoptera, and cosmopolitan in distribution with immense species richness and ecological importance. Beetles belong to this family attack to all types of plants as well as processed fibers and grains. Scavengers of this also play a crucial role in decomposition of organic nutrient. Scarabaeidae come into two main groups, one group including Coprinae, Aphodiinae, Geotrupinae and Troginae which are saprophagousTroginae, which are saprophagous, or fungus feeders and form another group 'Laprosticti'. The second group includes the subfamilies Melolonthinae, Rutelinae, Dynastinae and Cetoniinae which are mostly phytophagous. In world fauna of scarabaeids exceeds 30,000 species ((Mittal, 2000). Maximum numbers occur in the tropical areas, particularly in the African and Oriental regions. The family Scarabaeidae represents about 2,500 species from the Indian sub-continent from which the majority of the phytophagous scarabs belong to and the economically most important sub families include Melolonthinae, Rutelinae, Dynastinae and Cetoniinae. Grub stages of scarabaeidae are fleshy, white and the body is curved in ' $C$ ' form (Raodeo et al, 1987). Grubs stages are most destructive and troublesome soil insects in many areas of the world. White grubs are pests of national importance and cause extensive damage to field crops and fruit trees in India (Mehta et al, 2010). White grubs are dominant in certain endemic pockets of the states Rajasthan, Uttar Pradesh, Gujarat, Maharashtra and Karnataka. Adult beetles active during May-June and feed on the foliage parts of different fruit and forest trees (Mehta et al, 2008). Changes in biotic fauna and flora of natural habitats due to climate change and human interference in natural ecosystem has necessitated the need to have an inventory of species richness in an ecosystem. SoTherefore, the present study was undertaken to investigate the species diversity and abundance of scarabaeids in semiarid agro-ecosystem of Rajasthan.

\section{MATERIALS AND METHODS}

Materials required during the study were net, vials containing $70 \%$ alcohol and $4 \%$ formalin for preservations, plastic containers for temporary storage. Polythene bags for storing plant material for rearing purpose. A survey was carried out to find the scarabeid beetles and their host in the natural environment in the year 2019. The beetles were emerged after first shower of monsoon during evening; observations on the host range were made from $7.00 \mathrm{pm}$ to $11.00 \mathrm{pm}$ in the sampling site at selected locations (Table 1 ). Light traps were used for collection of the beetles from shelter plants and beetles collected were brought to the laboratory for further studies.

\section{Study area}

Cultivated area of different tehsil of Jaipur, Sikar and Nagour districts of Rajasthan, India were selected for installation of light traps (Table 2 ) and representative sites of different district were selected. The average annual rainfall was recorded from 500 to $550 \mathrm{~mm}$. Temperature range during summer, winter and rainy season ranges from $30^{\circ} \mathrm{C}$ to $48^{\circ} \mathrm{C}, 2^{\circ} \mathrm{C}$ to $29^{\circ} \mathrm{C}$ and $25^{\circ} \mathrm{C}$ to $39^{\circ} \mathrm{C}$, respectively. Soil was sandy loam to sandy soil and plant diversity, and good vegetative cover and harbors vegetation types ranging from seasonal grasses, herbs and climbers to perennial herbs, shrubs and trees. Rainy

\footnotetext{
${ }^{1}$ Division of Entomology, RARI, Durgapura, SKNAU, Jobner-302018, Rajasthan, India

2 SMS, KVK, Maulasar, AAU, Nagaur, Rajasthan, India
} 
season enjoys most greenery in the study region. The sampling was carried out during July to August,August 2019. Light trap data were collected daily and total counts were pooled for per month population. Adult beetles belonging to Scarabaeidae were sorted from samples. All specimens were preserved and identified to species level using taxonomic keys (Omkar and Bind 1996 and Omkar 2000) and cross checked with the help of specimens in the national museum at RARI, Durgapura, Jaipur.

Table 1: Locations of biodiversity and seasonality ofscarabaeid beetles

\begin{tabular}{|c|c|c|c|c|}
\hline $\begin{array}{l}\text { Study } \\
\text { sites }\end{array}$ & $\begin{array}{l}\text { Loca- } \\
\text { tions }\end{array}$ & $\begin{array}{l}\text { Latitude } \\
\text { DM }\end{array}$ & $\begin{array}{l}\text { Longitude } \\
\text { DM }\end{array}$ & $\begin{array}{l}\text { Elevation m } \\
\text { (asl) }\end{array}$ \\
\hline Jaipur & $\begin{array}{l}\begin{array}{l}\text { Durga- } \\
\text { pura }\end{array} \\
\text { Bobas } \\
\text { Chomu }\end{array}$ & $26^{0} 51 \mathrm{~N}$ & $75^{0} 47 \mathrm{E}$ & 390 \\
\hline & $\begin{array}{l}\text { Jobner } \\
\text { Palsana }\end{array}$ & & & \\
\hline Sikar & $\begin{array}{l}\text { Fateh- } \\
\text { pur } \\
\text { Regus }\end{array}$ & $27^{0} 56 \mathrm{~N}$ & $74^{0} 59 \mathrm{E}$ & 361 \\
\hline Nagaur & $\begin{array}{l}\text { Molasar } \\
\text { Nagour }\end{array}$ & $27^{0} 31 \mathrm{~N}$ & $74^{0} 75 \mathrm{E}$ & 352 \\
\hline
\end{tabular}

Statistical analysis Diversity indices

Study of different diversity indices were calculated to understand the diversity of insect community in space and time.

Alpha diversity

Numbers of species observed per site were considered as alpha diversity. Richness (number of species), abundance (number of individuals) and four indices were used to access species diversity of the area. Diversity indices were based on all the information recorded during study period from each site by using the following indices (Krebs, 2001) .

Species richness (S): Number of species in a habitat Species diversity index :

Common species richness index is based on the total number of species (S) and the total number of individuals of all species (N) in a habitat. Margalef's richness index: was calculated by given formula of Margalef (1968)

$\mathrm{Da}=(\mathrm{S}-1) /$ loge $\mathrm{N}$

$\mathrm{Da}=$ Margalef's richness index

Shannon-Wiener diversity index $\left(\mathrm{H}^{1}\right)$ : This index (Shannon and Weiner, 1963) was used to determine species diversity

$\mathrm{H}^{1}={ }^{\prime \prime} \mathrm{n}_{1} / \mathrm{N} \ln \mathrm{n}_{i} / \mathrm{N}$

Species evenness index (E): Was calculated as per Pielou (1975) $\mathrm{EI}=\mathrm{H}^{1} / \ln \mathrm{N}$

Species dominance index (D) : Was calculated as per Simpson (1949).

Shannon index
$H^{1}=-\sum_{i=1}^{s}\left(p_{i}\right)\left(\log _{2} p_{i}\right)$

Simpson's index of diversity

$D=1-\sum_{i=1}^{s}\left(p_{i}\right)_{2}$

Simpson's reciprocal index $=1 / \mathrm{D}$

where

$\mathrm{H}^{\prime}=$ Shannon diversity index

$\mathrm{pi}=$ Number of total sample to the ith species.

$\mathrm{S}=$ Number of species.

$\sum=$ Sum from species 1 to species $S$

$\mathrm{D}=$ Simpson's index of diversity.

$\mathrm{N}=$ Total number of organisms.

$\mathrm{n}=$ Percentage cover of a species

$\mathrm{J}^{\prime}=$ Evenness of allotment of individuals from the species.

$\mathrm{Hmax}=$ Maximum species diversity $\left(\mathrm{H}^{\prime}\right)=\log _{2} \mathrm{~S}$

Diversity dominance was drawn to assess the changes in abundance in each species from each locality. Properties and merit of each index has been discussed in details (Kempton 1979; Routledge 1979; Koleff et al 2003; Magurran 1988 \& Magurran 2004). A combination of indices, measure species richness, diversity and evenness are more important for the purpose ((Donald et al, 2004).

\section{RESULTS AND DISCUSSION}

Species distribution is important strategy for species specific management options. Previous reports provide list of scarab fauna in north India (Sreedevi et al, 2017). Geographical variations united with cropping pattern differences contribute to composition of species complex of an area. ThereforeTherefore, the present study, document the white grub species diversity and distribution pattern in the arid region of Rajasthan, India. Surveys conducted in Jaipur, Sikar and Nagour district of Rajasthan. The diversity indices assume that individuals are randomly sampled from infinitely large population. The Shannon index $\left(\mathrm{H}^{\prime}\right)$ explains the evenness of the abundance of species, while the Simpson's index of diversity (D) is less sensitive to species richness, but more sensitive to the most abundant species (Price 2004; Wilson and M 1988; Whittaker 1965; Chao 2004; Choudhary et al 2014). Pielou's evenness index $\left(\mathrm{J}^{\prime}\right)$ explains the evenness of allotment of individuals of different the species (Donald et al, 2004).

Total 9 species were recorded during the study period under 2 subfamilies of family Scarabaeidae .Scarabaeidae. The beetles collected during the study area were shown in different places. The details of beetles captured shown in Table 2 - The Scarabaeidae collected from three locations are listed in Table 2 . A total of 18885 specimens representing 9 different species of Scarabaeidae beetles were collected from different locations fromof Rajasthan. The identified species belong to subfamily Melolonthinae represented 6 species from the present study area. These are Holotrichia consanguinea, Holotrichia serrata, Maladera insanabilis, Maladera carninata, M. species and Schizonicha spp. The most important genera of the Melolonthinae family are Holotrichia, Apogonia, Maladera, and Leucopholis (Beeson 1941; Nair 2007; Butani 1979). 
In another subfamily Rutelinae are Anomala bengalensis, and A. dimidiata are polyphagus white grubs and dangerous pests of agricultural and horticultural crops. Present finding are supported by Sreedevi et al (2017) . In Rajasthan, H. consanguinea and $\mathrm{M}$. insanabilis, are the predominant species and serious pests of groundnut, bajra and jowar. Predominant species may be correlated with the cropping pattern to a large extent. The dominance of species and the richness of species varied from year to year and locality to locality (Table 3 ).

Table 2: Scarabaeid beetles species captured across the region

\begin{tabular}{|c|c|c|c|c|}
\hline \multirow[t]{2}{*}{ Species } & \multicolumn{3}{|c|}{$\begin{array}{l}\text { Total number of individ- } \\
\text { ual captured }\end{array}$} & \multirow{2}{*}{$\begin{array}{l}\text { Mean } \\
\text { no. of } \\
\text { indi- } \\
\text { vidua }\end{array}$} \\
\hline & Jaipur & Sikar & Nagour & \\
\hline H. consanguinea & 1903 & 3530 & 2345 & 2593 \\
\hline H. serrata & 34 & 67 & 41 & 47 \\
\hline Maladera carninata & 1097 & 610 & 910 & 872 \\
\hline Maladera insanabillis & 2654 & 2634 & 2525 & 2604 \\
\hline M. species & 23 & 0 & 0 & 8 \\
\hline Schizonicha sp & 13 & 43 & 16 & 24 \\
\hline Anomala bengalensis & 149 & 189 & 0 & 212 \\
\hline A. dimidiata & 14 & 32 & 26 & 24 \\
\hline Pachyrrhinadoretus frontatus & 30 & 0 & 0 & 10 \\
\hline Total number of species & 9 & 7 & 6 & 7 \\
\hline Total number of individual & 5917 & 7105 & 5863 & 6295 \\
\hline
\end{tabular}

The overall diversity of scarabaeid beetles in Rajasthan, observed by light trap catches. In Jaipur, the Simpson's index of diversity ( $\mathrm{D}=0.660$ ) was highest followed by Nagour ( $\mathrm{D}$ $=0.630)$ and lowest was recorded at Sikar $(D=0.607)$. Simpson's index of diversity $\left(S^{1}=0.3396\right)$ was recorded at Jaipur and highest at Sikar $\left(S^{1}=0.3924\right)$. The Simpson's reciprocal index was maximum at Jaipur $(\mathrm{RS}=2.945)$ and minimum at Sikar $(R S=2.548)$. Maximum Simpson's reciprocal index and minimum Simpson's index at Jaipur indicated that scarabaeid community at Jaipur consisted of maximum number of species with similar abundance (Table 4 ). The similar trend was also observed at Sikar and Nagour. At Nagour the species richness was found lower than the Jaipur. Jaipur found the highest Shannon index $\left(\mathrm{H}^{1}=1.235\right)$ and lowest was recorded at Sikar $\left(\mathrm{H}^{1}=1.093\right)$.

Table 3: Quantitative characteristic ofScarabaeid beetles species in agro ecosystem of the Rajasthan region

\begin{tabular}{lllllllll}
\hline \multicolumn{1}{c}{ Species } & Jaipur & \multicolumn{3}{c}{ Sikar } & \multicolumn{3}{c}{ Nagour } & \multicolumn{3}{c}{ Rajasthan } \\
& RF & RA & RF & RA & RF & RA & RF & RA \\
H. consanguinea & 32.16 & 9.99 & 49.68 & 18.54 & 40.00 & 12.31 & 41.18 & 13.61 \\
H. serrata & 0.57 & 0.20 & 0.94 & 0.40 & 0.70 & 00.24 & 0.75 & 0.28 \\
Maladera carninata & 18.54 & 5.76 & 8.59 & 3.20 & 15.52 & 4.78 & 13.85 & 4.58 \\
Maladera insanabilis & 44.85 & 13.94 & 37.07 & 13.83 & 43.07 & 13.26 & 41.37 & 13.67 \\
M. species & 0.39 & 0.27 & 0.00 & 0.00 & 0.00 & 00.00 & 0.12 & 0.09 \\
Schizonicha sp & 0.22 & 0.08 & 0.61 & 0.25 & 0.27 & 00.09 & 0.38 & 0.14 \\
Anomala bengalensis & 2.52 & 1.01 & 2.66 & 1.28 & 0.00 & 00.00 & 1.78 & 0.76 \\
A. dimidiata & 0.24 & 0.11 & 0.45 & 0.25 & 0.44 & 00.20 & 0.38 & 0.27 \\
Pachyrrhinadoretus frontatus & 0.51 & 0.47 & 0.00 & 0.00 & 0.00 & 00.00 & 0.01 & 0.15 \\
\hline
\end{tabular}


These values for Shannon index evenness index showed poor species richness, with least evenness in relative abundance of different species. Scarabeids community at Sikar was least diverse. This least diversity in Sikar may be due to associated cropping pattern. This unevenness of scarabaeid community was mainly found due to the dominance of $\mathrm{H}$. consanguinea, which comprised of more than $40 \%$ of total beetle catch in light traps. The Shannon index was maximum $\left(\mathrm{H}^{\prime}=1.235\right)$ at Jaipur and Evenness index 0.562 suggested maximum abundance of scarabaeid beetles species at Jaipur. There exists of a local variation among the different scarabaeid beetles, but the evenness was found high. A community dominated by few species is considered less diverse than one with a high species richness and evenness (Dhoj et al, 2009). There was a considerable variation in the diversity of scarabaeid beetles across locations with observation reported by several workers in the past (Chandel et al 1994; Anonymous 2008 \& Anonymous 2010). Variation in beetle diversity may be due to variation in seasonality, vegetation, crops sown, altitudeand altitude and soil type. Therefore, the present study results are discussed with species-specific integrated pest management

\section{REFERENCES}

Anonymous 2008. All India Network project on White Grubs and Other Soil Arthropods (Palampur, India. Annual Report) 2007-2015.

Anonymous 2010. All India Network project on White Grubs and Other Soil Arthropods (Palampur, India. Annual Report) 2009-2019.

Beeson C 1941. The Ecology and Control of the Forest Insects India the neighbouring Countries. In Delhi: Govt. of India.

Butani DK 1979. Insects and Fruits. Periodical book Agency, D-42 Vivek Vihar (Delhi) 415-415.

Chandel RS, Gupta PR and Chander R. 1994. Diversity of scarabaeid beetles in mid hills of Himachal Pradesh. Himachal Journal of Agriculture Research 20:98-101.

Chao A 2004. A Species richness estimation. In Encyclopedia of Statistical sciences, Wiley.

Choudhary JS, Naaz N, Mukherjee D, Prabhakar CS, Maurya S, Das B and Kumar S 2014.

Dhoj Y, Keller S, Nagel P and Kafle L. 2009. Abundance and diversity of scarabaeid beetles (Coleoptera: Scarabaeidae) in different farming areas of Nepal. Entomon 29:103-112.

Donald C, Smith R, M S and J D 2004. Using indices to measure biodiversity change through time. In International Workshop On Spatio-Temporal Modeling.

Kempton RA. 1979. The Structure of Species Abundance and Measurement of Diversity. Biometrics 35(1):307-307. url: https: //dx.doi.org/10.2307/2529952. doi: 10.2307/2529952

Koleff P, Gaston KJ and Lennon JJ. 2003. Measuring beta diversity for presence-absence data. Journal of Animal Ecology 72(3):367382. url: https://dx.doi.org/10.1046/j.1365-2656.2003.00710.x. doi: 10.1046/j.1365-2656.2003.00710.x

Krebs CJ 2001. Species diversity measures of heterogeneity. The Experimental Analysis of Distribution and Abundances (San Fransisco, USA: Wesley Longman Inc), 617-618.

Magurran AE 1988. Ecological Diversity and Its Measurement (Princeton, USA: Princeton University Press).

Magurran AE. 2004. Measuring Biological Diversity. Blackwell Science LTD . strategies should formulate for most abundance and diverse scarabaeids in semi-arid agro-ecosystem of Rajasthan.

Table 4: Parameters of abundance ofScarabaeid beetles in agro ecosystem of the Rajasthan region

\begin{tabular}{|c|c|c|c|c|c|c|c|c|}
\hline \multirow[b]{2}{*}{ Regions } & \multicolumn{8}{|c|}{ Diversity Indices } \\
\hline & $\mathrm{N}$ & S & $\mathrm{H}^{1}$ & $\mathrm{Da}$ & E & D & $S^{1}$ & RS \\
\hline Jaipur & 5917 & 9 & 1.235 & 0.9211 & 0.562 & 0.6604 & 0.3396 & 2.945 \\
\hline Sikar & 7105 & 7 & 1.122 & 0.6765 & 0.627 & 0.6076 & 0.3924 & 2.548 \\
\hline Nagour & 5863 & 6 & 1.093 & 0.5763 & 0.610 & 0.6305 & 0.3695 & 2.706 \\
\hline
\end{tabular}

$\mathrm{N}=$ Total number of individuals, $\mathrm{S}=$ Numbers of species, $\mathrm{H}^{1}=$ Shannon - Wiener diversity index, $\mathrm{Da}=$ Margalef's richness index, $\mathrm{D}=$ Dominance index, $\mathrm{E}=$ Evenness index, $\mathrm{S}^{1}=$ Simpson index, $\mathrm{RS}=$ Reciprocal Simpson index

\section{ACKNOWLEDGMENT}

We are grateful to the ICAR: AINP on Soil Arthropod Pest, Durgapura-Jaipur, for providing necessary assistance for this study under the project AINP on Soil Arthropod Pest.

Margalef R 1968. Perspectives in ecological theory. University of Chicago Press.p. 111.

Mehta PK, Chandel RS and Mathur YS. 2008. Phytophagous whitegrubs of Himachal Pradesh. Technical Bulletin: Department of Entomology, CSK HPKV.

Mehta PK, Chandel RS and Mathur YS. 2010. Status of whitegrubs in north western Himalaya. Journal of Insect Science 23:1-14.

Mittal IC. 2000. Survey of Scarabaeid (Coleoptera) fauna of Himanchal Pradesh (India). Journal of Entomology Research 24:133-141.

Nair K 2007.

Omkar and Bind RB. 1996. Records of aphid natural enemies complex of Uttar Pradesh. V. The coccinellids. J. Adv. Zool 17:44-48.

Omkar PA. 2000. New Record of coccinellids from Uttar Pradesh. II. J. Adv. Zool 21:43-47.

Pielou EC 1975. Ecological diversity (New York: Wiley and Sons).

Price DL. 2004. Species diversity and seasonal abundance of scarabaeid dung beetles (Coleoptera: Scarabaeidae, Geotrupidae and Trogidae) attracted to cow dung in central New Jersey. Journal of New York Entomological Society 112:334-347.

Raodeo AK, Deshpande SMS and India. 1987. White Grubs and their management. Research Bulletin Marathawada Agricultural University Parbhani .

Routledge RD. 1979. Diversity indices: Which ones are admissible? Journal of Theoretical Biology 76(4):503-515. url: https: //dx.doi.org/10.1016/0022-5193(79)90015-8. doi: 10.1016/00225193(79)90015-8

Simpson EH. 1949. Measurement of Diversity. Nature 163(4148):688688. url: https://dx.doi.org/10.1038/163688a0. doi: 10.1038/ $163688 \mathrm{a} 0$

Sreedevi K, Tyagi S and Sharma V. 2017. Species Diversity of White Grubs (Coleoptera:Scarabaeidae) in the Sub-Himalayan and Northern Plains of India. Current Science 113(02):322-322. url: https://dx.doi.org/10.18520/cs/v113/i02/322-329. doi: 10. 18520/cs/v113/i02/322-329

Whittaker RH. 1965. Dominance and diversity in plant communities. Science 147:250-260.

Wilson EO and M F 1988. Biodiversity. An important collection of papers that launched public awareness of biodiversity and its importance (Washington DC, USA: National Academy Press). 
Citation:

Jakhar BL, Baloda A, Choudhary M, Saini KK, Jakhar ML and Yadav T. 2021. Biodiversity of White Grub, (Coleoptera: Scaraeidae) in Semi-Arid Agro-Ecosystem of Rajasthan. Journal of AgriSearch 8(2): 112-116 